\title{
THE CONTRIBUTION OF PERCEIVED COLLECTIVE EFFICACY BELIEFS AND INTERPERSONAL EMOTION REGULATION TO TURKISH EFL TEACHERS' JOB STRESS
}

\author{
Ilknur Eginli ${ }^{i}$, \\ Aynur Kesen Mutlu \\ Istanbul Medipol University, \\ Istanbul, Turkey
}

\begin{abstract}
:
The goal of this study was to explore the relationship between perceived job stress and a specific set of predictor variables among the selected university preparatory school EFL (English as a Foreign Language) teachers in Turkey. To comprehensively analyze the issue of perceived job stress, interpersonal emotion regulation, and teacher collective efficacy used as variables. The sample consisted of 48 EFL teachers in various Turkish university preparatory schools. It was hypothesized that high levels of teacher collective efficacy beliefs would be a negative predictor of perceived stress among the EFL teachers. A negative relationship was also predicted between interpersonal emotion regulation and perceived job stress levels among the selected teachers. The research hypotheses were tested using data collected through surveys. While the relationship between EFL teachers' collective efficacy beliefs and interpersonal emotion regulation was significant, their perceived job stress and interpersonal emotion regulation were negatively related, but the association was not strong enough to reach a significant level. The results of the study indicated that demographic variables such as age, and the years of language teaching experience did not have any significant effect on teachers' collective self-efficacy belief, perceived job stress, and interpersonal emotion regulation of the selected Turkish EFL Instructors in university preparatory programs. The study highlighted the fact that enhancing EFL teachers' collective efficacy belief would reduce the tension teachers experience in the form of stress and would improve their emotion regulation skills.
\end{abstract}

Keywords: collective efficacy beliefs, interpersonal emotion regulation, perceived job stress

\footnotetext{
' Correspondence: email ilknur.eginli@gmail.com
} 


\section{Introduction}

The widespread claim that 'teaching is a stressful job' is well-supported by the empirical studies in the field of education (Borg \& Riding, 1991; Dawn et al., 2017; Smith et al., 2000; McCarthy et al., 2010; Stoeber \& Rennert, 2008). Though the causes of stress differ from person to person, in an attempt to scrutinize this emotional stage, it is valuable to evaluate the reasons why teachers feel tense about their job. Some of the major sources of stress for teachers listed by Kyriacou (2001) are workload demands, classroom management issues, students with low or no motivation, challenging relationships with administrators and colleagues. When job stress come in different forms, it is very likely that an individual's mind and body could be negatively affected.

Following this vein, Jepson and Forrest (2006) asserted work-related stress in the profession of teaching damages teachers' both psychological and physical health. Given that, a stressful professional lifestyle may lead teachers to perform their tasks poorly, there is a great need for teachers to receive sustainable support in their work setting.

When taking the English Language Teaching context into consideration, language teachers are no different in terms of experiencing mental and physical pressure due to work-related psychological distress. This applies even more so to the language teachers as they have unique job-related stressors (Weinstein \& Trickett, 2016) while performing multiple tasks in the classroom. First and foremost, language learning should be fun, and to get the best out of their students' English language teachers need to regularly motivate their learners to actively participate in classroom activities (Good \& Brophy, 1994; Dornyei, 2001).

The relevant job stress literature review in the English language teaching profession in Turkey is also in line with most of the stated job stressors earlier; unmotivated students, distortion in teacher role and responsibilities, the lack of administration and peer cooperation, inadequate resources and in-service education, crowded classrooms, poor organizational structure (Bulut, 2005; Pehlivan-Aydın, 2002). As teaching can be described as a form of emotional labor ((Sutton, Mudrey-Camino and Knight, 2009; Zemblas, 2002), just like in other professions it requires employees to manage their emotions. In a study Klassen et al. (2010) conducted, the researchers firmly asserted that teachers in the field are not offered seminars or workshops that would teach them necessary coping strategies to manage stress at work. Despite the increasing awareness of work-related stress among teachers, existing research has not sought to explain the association between language teachers' interpersonal emotion regulation and collective efficacy beliefs pertaining to job stress of EFL teachers working at preparatory schools in Turkish universities. Therefore, the purpose of the present study is to extend the current research of EFL teachers' job stress; more specifically, the relationship between EFL teachers' job stress, their collective efficacy beliefs and interpersonal emotion regulation will be examined. As such, the following hypotheses are formulated:

1) High levels of collective efficacy beliefs would be negative predictors of perceived stress among the selected EFL Preparatory School teachers in Turkey. 
2) High levels of interpersonal emotion regulation would be negative predictors of perceived stress among the selected EFL Preparatory School teachers in Turkey.

3) Age does not have any significant effect on EFL Preparatory School teachers' perceived job stress, collective efficacy, and interpersonal emotional regulation.

4) Years of teaching experience does not have any effect on perceived job stress, collective efficacy, and interpersonal emotional regulation.

5) There are strong relationships between perceived job stress, collective efficacy, and interpersonal emotional regulation.

6) Collective efficacy and interpersonal emotional regulation are good predictors of perceived job stress.

\section{Literature Review}

\subsection{Job Stress}

Stress, as a general term, can be defined as the emotional and physical reaction of one's body to a harmful situation. Lazarus and Lazarus $(1994,1999)$ described psychological stress, they mainly focused on the negative effect of undesired environmental factors the individuals find themselves and not being able to cope with the demands of the outside world. Therefore, when there is a concern about people' emotional distress, the display of emotions in social functioning needs to be scrutinized.

Teacher job stress is defined by Chris Kyriacou (2001) as a mismatch between the demand of employers and teachers' abilities to cope with those demands and pressures. He noted teaching as being one of the high-stress jobs; and teachers are exposed to various sources of stress, in turn, have negative feelings such as frustration, depression, and anxiety towards their work experience. The determinants of teacher stress can be an increase in teacher workload, a tension between teacher and supervisors, parents, or students, or perceived lack of professional growth opportunities (O'Connor \& Clark, 1990; Sass, Seal, \& Martin, 2011). Kyriacou (2000) goes further and claims that the highstress level felt in the teaching profession can sometimes be as close as what health professionals, people in prison service or police departments experience. Professionals in all of the former jobs have to have direct contact with others to perform their tasks just like in teaching. Language teachers work directly with individuals, and the kinds of stress experienced by them can cause various health issues the results of which could influence students, other co-workers, their work setting as a whole.

In the field of foreign and second language education, Borg (1990) firmly stated that teaching is regarded as a highly stressful job even at the international level. EFL teachers' perceived job stress can have detrimental effects both on individuals and organizations. In Turkey, Ipek et al. (2018) examined the relationship between perceived occupational stress and self-efficacy beliefs of 84 EFL teachers working in a public university's English Language Preparation Program. The results revealed no significant relationship between teachers' efficacy beliefs and stress, and no significant relationships in demographical variables. The authors concluded that external factors such as school 
policies, the administrative structure may have been contributed to the results of the study. Thus, in this study, as also recognized by other researchers (Bracket et al. 2010; Naring, Briet \& Brouwers 2006), the relationship between job stress and the emotional aspect of it and collective efficacy beliefs are scrutinized.

\subsection{Collective Efficacy Beliefs}

In the efficacy literature, the ways in which teachers' perception of individual and group capabilities influence their actions have been a burgeoning area of inquiry ever since the social cognitive theory was developed by Albert Bandura in 1993. Bandura distinguishes three modes of human agency: 1- Individual, 2- Proxy, and 3- Collective.

Self-efficacy beliefs provide the foundation of human motivation, and individuals' beliefs can be influenced by all the happenings around them. Therefore, people sometimes exercise socially mediated agency which is called the proxy agency in which they seek the assistance of experts in their fields (Bandura, 2000). And, people's shared beliefs in their group abilities are essential for the collective agency (Bandura, 1993, 1997, 2000, 2002).

Since collective efficacy concerns an individual's judgment in the group capabilities, i.e. how one feels about the group shared capabilities (Goddard \& LoGerfo, 2007), teachers' sense of belonging in school, their efficacy as it relates to organizational context, especially in terms of commitment to school and job satisfaction have been widely investigated (Caprara, Barbaranelli, Borgogni \& Petitta, 2003; Ciani, Summers, \& Easter, 2008; Friedman \& Kass, 2002; Ross \& Gray, 2006). Teachers with a high level of collective efficacy beliefs, a school-level factor, may be those who experience supportive relationships with their colleagues, parents, administrators, and students (Goddard \& Goddard, 2001). Scott, Stone and Dinham (2001) recommended strong relationships among colleagues as a fundamental requirement for teacher commitment. They also suggested encouragement and expanded support among colleagues as a key strategy to create high job satisfaction in the work setting. Over the last three decades, highly satisfied teachers in the profession are found to have "collegial, collaborative" relationships with colleagues (Green \& Manke, 2001). To examine this phenomenon in greater detail many researchers, in the field of education and educational psychology, examined the relationship between teachers' collective efficacy beliefs and various personal and social-contextual factors such as teacher empowerment, self-efficacy, teachers' motivation and well-being; professional learning communities, school effectiveness, instructional leadership, teacher collaboration (Baleghizadeh \& Goldouz, 2016; Goddard et al., 2015; Voelkel \& Chrispeels, 2017; Klassen, Usher, \& Bong, 2010; Stephanou \& Oikonomou, 2018).

A review of two decades of empirical studies refers that there is a linear relationship between school contextual factors and individual and collective beliefs. In collective teacher efficacy literature, however, studies in ELT context are limited, and studies exploring the relationship between language teachers' collective efficacy their emotion regulation are quite scarce. Moreover, little research has focused on whether 
collective teachers' efficacy impacts job satisfaction (Caprara, Barbaranelli, Borgogni, \& Steca, 2003; Klassen, 2010). Therefore, the purpose of this study is to investigate how practicing English language teachers' interpersonal emotion regulation and collective efficacy beliefs influence their perceived job stress in an EFL setting.

\subsection{Interpersonal Emotion Regulation}

Emotions are experienced in everybody's life on a regular basis, and emotion regulation is individuals' ability to manage their emotions (McRae et al., 2009). Execution of emotion regulation models leads to a healthy personal and professional life (John \& Gross, 2004). As a result, individuals cope with stress (Garnefski \& Kraaij, 2006; Gross, 2001).

Since interpersonal factors are highly valuable in emotion regulation (Hoffman, 2016), and the profession of teaching is based on social relations, it is essential to scrutinize teachers' interpersonal emotion regulation within a social context. Given that emotion regulation can also be considered a useful cognitive strategy (Kross, Ayduk, Mischel, 2005), it can create both positive and negative emotions whereas coping is only concerned about decreasing negative results (Gross 2001; 2015). Conversely, difficulties in emotion regulation cause health problems (Rude \& McCarthy, 2003), negative psychological states (Kashdana et al., 2006). Therefore, it seems natural that one should raise the question as to why some teachers suffer stress, emotional burden, or burnout. Along the same lines, emotional aspects of teaching are a widely ignored area of study in the field of teaching (Sutton \& Wheatley 2003; Sutton 2005).

Teachers' emotion regulation is associated with teacher efficacy, teachers' job satisfaction, well-being and, burnout (Brackett et al., 2010; Greenier et al., 2021). Recently, Fathi et al. (2021) conducted a mediation study to investigate the mediating role of emotion regulation between Iranian EFL teachers' self-efficacy beliefs and influences of reflection on teacher burnout. They administered four questionnaires to 238 instructors teaching in various types of language institutes in the country. The results revealed that the variables may lead to the mitigation of the probability of EFL instructors experiencing negative feelings towards their job, i.e. burnout in their profession. It bears emphasizing that when individuals seek help, they manage to cope with the negative feelings (Williams, Morelli, Ong \& Zaki, 2018). That is to say, social support and sharing could help overcome the challenges in regulating their emotions. There is a lack of research in examining the association between teachers' perceived job stress and interpersonal emotion regulation.

\section{Material and Methods}

\subsection{Participants}

The participants of this study are 48 EFL teachers working at preparatory school of various universities in Turkey. 


\subsection{Measurements}

\section{a. Perceived Stress Scale}

The measure of psychological stress is the Perceived Stress Scale (PSS) in this study is an instrument that measures to what extent one's life is stressful (Cohen, Kamarck and Mermelstein,1983). This self-report instrument consisting of ten items assess how "how unpredictable, uncontrollable, and overloaded respondents find their lives" when objective measures of stress are provided. The PSS rated on a 5-point Likert scale, ranging from 0 (never) to 4 (very often). Total scores range from 0 to 40 . Reliability of this instrument based on three tests and the Cronbach's alpha coefficient scores for each test respectively were 0.84, 0.85 and 0.86 (Cohen, Kamarck and Mermelstein 1983).

\section{b. Collective Efficacy Scale}

Goddard (2002) created the 12-item short form of the Collective Efficacy Scale (CES), which is based on the Teacher Efficacy Belief Scale developed by Gibson and Dembo (1984), to measure teachers' perceived collective efficacy. CES rated on a 6-point Likert type scale anchored at 1 (strongly disagree) and 6 (strongly agree). A sample item in this scale reads "Teachers in this school are able to get through to different students." The reported reliability score for the 12-item scale is (alpha $=0.94)$ with a high internal consistency (alpha $=.94)($ Goddard 2002).

\section{c. Interpersonal Emotion-regulation Questionnaire}

Interpersonal Emotion Regulation Questionnaire (IERQ) developed by Hofmann et al. (2016) was used in order to measure how teachers' regulate their emotions. This questionnaire is a 20-item self-report scale and has four subscales as follow: increasing positive emotions, perspective taking, relaxation and social modeling. The measures of 1, 2, 3, 4 and 5 are graded respectively for each statement. Hofmann et al. (2016) IERQ, a being a valid and reliable self-report questionnaire. IERQ's internal consistency reliability (Cronbach's alpha coefficient) was calculated as in the following: 0.87 for the increasing positive emotions, 0.85 for the perspective-taking, 0.89 for the relaxation, and 0.91 for the social modeling (Hofmann et al., 2016).

\subsection{Analyzing of Data}

The first two hypotheses of this study were:

1) High levels of collective efficacy belief would be a negative predictor of perceived stress among the selected EFL Preparatory School teachers in Turkey.

2) High levels of interpersonal emotion regulation would be a negative predictor of perceived stress among the selected EFL Preparatory School teachers in Turkey.

To examine these two hypotheses the totals of the respondents' answers to the items relating to these two attributes in the questionnaire were calculated and their means were used as the cut points to factor out cases with low collective efficacy belief and interpersonal emotion regulation. Table 1 shows the means of collective efficacy belief and interpersonal emotion regulation. 
Table 1: Means of Collective Efficacy Belief and Interpersonal Emotion Regulation

\begin{tabular}{|l|c|c|}
\hline & N & Mean \\
\hline Collective efficacy belief & 48 & 33.0000 \\
\hline Interpersonal emotion regulation & 48 & 61.8542 \\
\hline Valid N (listwise) & 48 & \\
\hline
\end{tabular}

To see if high levels of collective efficacy belief and interpersonal emotion regulation could negatively predict perceived job stress among the selected EFL Preparatory School teachers in Turkey, simple regressions were run with the values of these attributes that were above their means. Tables from 2 to 5 present results of the analysis for collective efficacy belief. The assumptions of regression such as linearity, multicollinearity, lack of influential cases, independence of errors, homosedasticity, normally distributed errors, variable type, and non-zero variance were either met or not applicable to this analysis at all. For example, the assumption of non-zero independence means that the predictors should have some variation in value while in this analysis there was only one predictor. Also, both the predictor and the outcome variables were linearly related and internally measured.

Table 2: Method of Entry for High Levels of Collective Efficacy Belief

\begin{tabular}{|l|c|c|c|}
\hline Model & Variables Entered & Variables Removed & Method \\
\hline 1 & Collective efficacy belief ${ }^{\mathrm{b}}$ &. & Enter \\
\hline a. Dependent variable: Perceived job stress \\
\hline \multicolumn{2}{|l}{ b. All requested variables entered. } \\
\hline
\end{tabular}

Table 3: Model Summary for High Levels of Collective Efficacy Belief

\begin{tabular}{|c|c|c|c|c|}
\hline Model & $\mathbf{R}$ & $\mathbf{R}$ Square & Adjusted R Square & Std. Error of the Estimate \\
\hline 1 & $.306^{\mathrm{a}}$ & .094 & .051 & 6.09078 \\
\hline
\end{tabular}

Table 4: ANOVA Result for High Levels of Collective Efficacy Belief

\begin{tabular}{|l|l|c|c|c|c|c|}
\hline \multicolumn{2}{|l|}{ Model } & Sum of Squares & df & Mean Square & F & Sig. \\
\hline \multirow{3}{*}{1} & Regression & 80.691 & 1 & 80.691 & \multirow{2}{*}{2.175} & \multirow{2}{*}{$.155^{\mathrm{b}}$} \\
\cline { 2 - 7 } & Residual & 779.048 & 21 & 37.098 & & \\
\cline { 2 - 6 } & Total & 859.739 & 22 & & & \\
\hline
\end{tabular}

Table 5: Coefficients for High Levels of Collective Efficacy Belief

\begin{tabular}{|c|c|c|c|c|c|c|}
\hline \multirow{2}{*}{\multicolumn{2}{|c|}{ Model }} & \multicolumn{2}{|c|}{$\begin{array}{l}\text { Unstandardized } \\
\text { Coefficients }\end{array}$} & \multirow{2}{*}{$\begin{array}{c}\begin{array}{c}\text { Standardized } \\
\text { Coefficients }\end{array} \\
\text { Beta } \\
\end{array}$} & \multirow[t]{2}{*}{$\mathbf{t}$} & \multirow[t]{2}{*}{ Sig. } \\
\hline & & B & Std. Error & & & \\
\hline \multirow[t]{2}{*}{1} & (Constant) & 34.810 & 10.473 & & 3.324 & .003 \\
\hline & Collective efficacy belief & -.394 & .267 & -.306 & -1.475 & .155 \\
\hline
\end{tabular}

a. Dependent variable: Perceived job stress 
Since this is a simple regression, that is there is only one predictor variable, the significance values for ANOVA (Table 4) and Beta coefficient for collective efficacy belief (Table 5) are the same. Both of these values are non-significant ( $p=.155>.05)$ calling attention to the point that high levels of collective efficacy belief are not a good negative predictor of perceived job stress among the selected EFL Preparatory School teachers in Turkey.

The same line of analysis was also run to find out if interpersonal emotion regulation is an effective negative predictor of stress among the selected EFL Preparatory School teachers in Turkey or not. Tables 6 to 9 show the results of this analysis.

Table 6: Method of Entry for High Levels of Interpersonal Emotion Regulation

\begin{tabular}{|c|c|c|c|}
\hline Model & Variables Entered & Variables Removed & Method \\
\hline 1 & Interpersonal emotion regulation ${ }^{\mathrm{b}}$ & & Enter \\
\hline a. Dependent variable: Perceived job stress & \\
\hline b. All requested variables entered.
\end{tabular}

Table 7: Model Summary for High Levels of Interpersonal Emotion Regulation

\begin{tabular}{|c|c|c|c|c|}
\hline Model & $\mathbf{R}$ & R Square & Adjusted R Square & Std. Error of the Estimate \\
\hline 1 & $.221^{\text {a }}$ & .049 & -.001 & 6.67090 \\
\hline \multicolumn{2}{|l}{ a. Predictors: (Constant), Interpersonal emotion regulation } \\
\hline
\end{tabular}

Table 8: ANOVA Result for Interpersonal Emotion Regulation

\begin{tabular}{|l|l|c|c|c|c|c|}
\hline \multicolumn{2}{|l|}{ Model } & Sum of Squares & df & Mean Square & F & Sig. \\
\hline \multirow{3}{*}{1} & Regression & 43.436 & 1 & 43.436 & \multirow{2}{*}{.976} & \multirow{2}{*}{$.336^{\mathrm{b}}$} \\
\cline { 2 - 6 } & Residual & 845.517 & 19 & 44.501 & & \\
\cline { 2 - 7 } & Total & 888.952 & 20 & & & \\
\hline
\end{tabular}

Table 9: Coefficients of High Levels of Interpersonal Emotion Regulation

\begin{tabular}{|c|c|c|c|c|c|c|}
\hline \multirow{2}{*}{\multicolumn{2}{|c|}{ Model }} & \multicolumn{2}{|c|}{$\begin{array}{c}\text { Unstandardized } \\
\text { Coefficients }\end{array}$} & \multirow{2}{*}{$\begin{array}{c}\begin{array}{c}\text { Standardized } \\
\text { Coefficients }\end{array} \\
\text { Beta } \\
\end{array}$} & \multirow[t]{2}{*}{$\mathbf{t}$} & \multirow[t]{2}{*}{ Sig. } \\
\hline & & B & Std. Error & & & \\
\hline \multirow[t]{2}{*}{1} & (Constant) & 31.963 & 12.244 & & 2.611 & .017 \\
\hline & Interpersonal emotion regulation & -.155 & .157 & -.221 & -.988 & .336 \\
\hline
\end{tabular}

As with collective efficacy belief, high levels of interpersonal emotion regulation is not a good negative predictor of the selected EFL Preparatory School teachers' perceived job stress in Turkey $(p=.336>.05)$.

The third hypothesis was related to the effect of age on EFL Preparatory School teachers' perceived job stress, collective efficacy, and interpersonal emotional regulation. The hypothesis was formulated in the following way:

- Age does not have any significant effect on EFL Preparatory School teachers' perceived job stress, collective efficacy, and interpersonal emotional regulation. 
The hypothesis as it stands has one independent and three dependent continuous variables the testing of which requires running a one-way multivariate analysis of variance or MANOVA. Assumptions of MANOVA were examined first. Five assumptions of MANOVA are shared with other linear models. They are linearity, interval level of measurement, the randomness of the sample, independence of scores, and normality of the population distribution of scores. These assumptions do not need examination here because they are met by default, some because of sample size (central theorem hypothesis) and others because of the measurement scale of the variables.

The remaining assumptions are (1) Homogeneity of variance-covariance matrices: this assumption requires almost equal variances for dependent variables. In the same way, it requires similar correlations between pairs of all dependent variables. This assumption is tested by Box's variance-covariance matrices test the sig value of which should be larger than .001. (2) Outliers: in relation to outliers, we should see if there is an outlier in the sample and if yes, whether it exerts excessive influence on the regression model. The existence of an outlier was tested by Mahallanobis distance and whether or not it exerts an excessive effect was tested by Cook's distance. For a model with three dependent variables, the Mahal distance should be smaller than 16.27; the Cook's distance is acceptable within the \pm 2 range but we prefer it to be as close as possible to zero. (3) Multicollinearity and singularity: this assumption means that the dependent variables should not correlate highly with each other. It is clear that if dependent variables correlate very highly with each other (above .80) it would mean that they are measuring the same construct. This assumption can easily be examined using a correlation matrix. The following 3 tables were generated for checking these three assumptions.

Table 10: Box's Test of Equality of Covariance Matrices

\begin{tabular}{|l|c|}
\hline Box's M & 10.028 \\
\hline F & .734 \\
\hline df1 & 12 \\
\hline df2 & 4766.288 \\
\hline Sig. & .720 \\
\hline
\end{tabular}

Table 11: Mahallanobis and Cook's Distances

\begin{tabular}{|l|c|c|c|c|c|}
\hline & Minimum & Maximum & Mean & Std. Deviation & N \\
\hline Mahal. Distance & .285 & 10.280 & 2.938 & 2.527 & 48 \\
\hline Cook's Distance & .000 & .232 & .023 & .040 & 48 \\
\hline a. Dependent variable: Age & \multicolumn{5}{|l|}{} \\
\hline
\end{tabular}


Table 12: Correlations between Dependent Variables

\begin{tabular}{|l|l|c|c|c|}
\hline \multicolumn{2}{|c|}{} & $\begin{array}{c}\text { Collective } \\
\text { efficacy belief }\end{array}$ & $\begin{array}{c}\text { Perceived job } \\
\text { stress }\end{array}$ & $\begin{array}{c}\text { Interpersonal emotion } \\
\text { regulation }\end{array}$ \\
\hline \multirow{2}{*}{$\begin{array}{l}\text { Collective } \\
\text { efficacy } \\
\text { belief }\end{array}$} & Pearson Correlation & 1 & $-.351^{*}$ & $.556^{* *}$ \\
\cline { 2 - 5 } & Sig. (2-tailed) & & .014 & .000 \\
\cline { 2 - 5 } \begin{tabular}{l}
\multirow{2}{*}{$\begin{array}{l}\text { Perceived } \\
\text { job } \\
\text { stress }\end{array}$} \\
\cline { 2 - 5 }
\end{tabular} & Pearson Correlation & $-.351^{*}$ & 48 & 48 \\
\cline { 2 - 5 } & Sig. (2-tailed) & .014 & 1 & -.140 \\
\cline { 2 - 5 } & $\mathrm{N}$ & 48 & 48 & .344 \\
\hline
\end{tabular}

The fact that Box's test significance value is much larger than $.001(p=.720>.05)$ means that the assumption of dependent variables equal variances has not been violated. Maximum Mahallonobis distance is 10.280 , which is much smaller than the critical value for three independent variables (16.27) meaning that there has been no outlier. On the other hand, Cook's distance is well around zero pointing to the fact that no case has been exerting undue influence on the model. And finally, the correlation matrix shows that none of the correlations between independent variables approaches the high level of .80. All these findings lead to a firm ground to go ahead with running MANOVA.

MANOVA generates three main tables. The first of these tables is called BetweenSubjects Factors Table shows the number of participants falling in each level of the independent variable. This table is the same as Table 13 below.

Table 13: Between-Subjects Factors

\begin{tabular}{|l|c|l|c|}
\hline \multicolumn{2}{|c|}{ Age } & Value Label & N \\
\cline { 2 - 4 } & 1 & under 22 & 3 \\
\cline { 2 - 4 } & 2 & $22-32$ & 12 \\
\cline { 2 - 4 } & 3 & $33-43$ & 19 \\
\cline { 2 - 4 } & 4 & $44-54$ & 11 \\
\cline { 2 - 4 } & 5 & $55-65$ & 3 \\
\hline
\end{tabular}

The second table or the Multivariate Tests Table is a very important table because it shows whether the independent variable has had any effect on the dependent variables, if it had any effect at all, regardless of which dependent variable it was.

Table 14: Multivariate Tests for the Effect of Age

\begin{tabular}{|l|l|c|c|c|c|c|}
\hline \multicolumn{2}{|l|}{ Effect } & Value & F & Hypothesis df & Error df & Sig. \\
\hline \multirow{5}{*}{ Age } & Pillai's Trace & .154 & .582 & 12.000 & 129.000 & .854 \\
\cline { 2 - 7 } & Wilks' Lambda & .851 & .568 & 12.000 & 108.767 & .863 \\
\cline { 2 - 7 } & Hotelling's Trace & .168 & .556 & 12.000 & 119.000 & .873 \\
\cline { 2 - 6 } & Roy's Largest Root & .114 & $1.230^{c}$ & 4.000 & 43.000 & .312 \\
\hline
\end{tabular}


This table, as it is generated by SPSS, has two halves, the upper half and the lower half. The upper half provides tests for the intercept of the model and is deleted here because it is not needed for our conclusions. The four tests in the lower half, the results of which are presented here in Table 14, are all almost the same with the difference that some of them are more liberal than others which are conservative. Regardless of which test we take into consideration, all of them reveal that age does not have any significant effect on dependent variables in this study.

The results of this table determine the importance of the forthcoming Tests of Between-Subjects Effects Table. If one or all of the multivariate tests are significant, we can expect to find a significant effect for the independent variable that it exerts on one or more dependent variables. If they are not significant, we would naturally expect to find no significant effects as is the case in the following table in the row headed by age. Nonessential parts of this table are also deleted for space considerations.

Table 15: Tests of Between-Subjects Effects

\begin{tabular}{|l|l|c|c|c|c|c|}
\hline Source & Dependent Variable & $\begin{array}{c}\text { Type III Sum } \\
\text { of Squares }\end{array}$ & df & $\begin{array}{c}\text { Mean } \\
\text { Square }\end{array}$ & F & Sig. \\
\hline \multirow{4}{*}{ Age } & Collective efficacy belief & 171.890 & 4 & 42.973 & .831 & .513 \\
\cline { 2 - 7 } & Perceived job stress & 137.303 & 4 & 34.326 & .607 & .660 \\
\cline { 2 - 7 } & Interpersonal emotion regulation & 985.566 & 4 & 246.392 & .920 & .461 \\
\hline \multirow{2}{*}{$\begin{array}{l}\text { Corrected } \\
\text { Total }\end{array}$} & Collective efficacy belief & 2396.000 & 47 & & & \\
\cline { 2 - 7 } & Perceived job stress & 2568.979 & 47 & & & \\
\cline { 2 - 7 } & Interpersonal emotion regulation & 12495.979 & 47 & & & \\
\hline
\end{tabular}

Manifestly, age does not have any significant effect on collective self-efficacy belief ( $p$ $=.513>.05)$, perceived job stress $(\mathrm{p}=.666>.05)$, and interpersonal emotion regulation $(\mathrm{p}$ $=.461>.05$ ). Hypothesis four is very similar to hypothesis three with the only difference that in this case the effect of years of language teaching experience on the same dependent variables is expected to be explored. The hypothesis is:

- Years of teaching experience does not have any significant effect on perceived job stress, collective efficacy, and interpersonal emotional regulation.

Since all assumptions of MANOVA were already tested, we simply repeated the analysis with years of language teaching experience as our independent variable. Tables 16,17 , and 18 provide us with the results of this test. Table 16 shows the number of teachers falling in each category.

Table 16: Number of Teachers Falling in each Category

\begin{tabular}{|l|l|l|c|}
\hline \multicolumn{2}{|l|}{} & Value Label & $\mathbf{N}$ \\
\hline Years of language & 1 & less than a year & 7 \\
\cline { 2 - 4 } & 2 & $1-3$ years & 3 \\
\cline { 2 - 4 } & 3 & $4-7$ years & 7 \\
\cline { 2 - 4 } & 4 & $8-15$ years & 12 \\
\cline { 2 - 4 } & 5 & $15+$ & 19 \\
\hline
\end{tabular}


The multivariate tests table shows that age, years of language teaching experience does not have any significant effect on collective self-efficacy belief, perceived job stress, and interpersonal emotion regulation of preparatory school teachers in Turkey. We can go with the Tests of Between-Subjects Effects Table in this round of analysis, because according to the multivariate tests' results that no significant effect for the independent variable on dependent variables will be identified.

Table 17: Multivariate Tests for the Effect of Years of Language Teaching Experience

\begin{tabular}{|l|l|c|c|c|c|c|}
\hline Effect & Value & F & Hypothesis df & Error df & Sig. \\
\hline \multirow{2}{*}{$\begin{array}{l}\text { Years of language } \\
\text { teaching experience }\end{array}$} & Pillai's Trace & .184 & .704 & 12.000 & 129.000 & .745 \\
\cline { 2 - 7 } & Wilks' Lambda & .821 & .700 & 12.000 & 108.767 & .748 \\
\cline { 2 - 7 } & Hotelling's Trace & .211 & .696 & 12.000 & 119.000 & .752 \\
\cline { 2 - 7 } & Roy's Largest Root & .170 & $1.830^{c}$ & 4.000 & 43.000 & .141 \\
\hline
\end{tabular}

The fifth hypothesis was formulated to seek the relationship between perceived job stress, collective efficacy belief, and interpersonal emotion regulation. The hypothesis was:

- There are strong relationships between perceived job stress, collective efficacy, and interpersonal emotional regulation.

We actually have tested this test before while examining the MANOVA assumptions that we ran in testing the third hypothesis. Based on the correlations run, collective efficacy belief and perceived job stress are negatively related and the relationship is significant $(\mathrm{r}=-.351, \mathrm{p}=.014<.05)$. Collective self-efficacy belief and interpersonal emotion regulation are positively related and the relationship is significant $(\mathrm{r}=.556, \mathrm{p}=.000<.05)$. Perceived job stress and interpersonal emotion regulation are negatively related but the association is not so strong to reach a significant level $(r=-.140$, $\mathrm{p}=.344>.05)$. Two of the relationships are significant.

The sixth or last hypothesis is very similar to the first two hypotheses other than that it seeks to test collective efficacy belief and interpersonal emotional regulation's prediction power of preparatory teachers' job stress regardless of whether the attributes are high or low in their intensity.

Collective efficacy and interpersonal emotional regulation are good predictors of perceived job stress. We were unable to run a multiple regression to test the first two hypotheses together because we had to filter out teachers with low collective efficacy belief and low interpersonal emotion regulation and the teachers' these two attributes did not match in their intensity. But to test the last hypothesis, a multiple regression was run since all teachers needed to be included in the analysis. Table 18 is indicative of the method used for data entry. 


\begin{tabular}{|c|c|c|c|}
\hline \multicolumn{4}{|c|}{ Table 18: Data Entry Method } \\
\hline Model & Variables Entered & Variables Removed & Method \\
\hline 1 & $\begin{array}{c}\text { Collective efficacy belief, } \\
\text { Interpersonal emotion regulation }\end{array}$ & & Enter \\
\hline a. Dependent variable: Perceived job stress & & \\
\hline b. All requested variables entered.
\end{tabular}

In the Model Summary Table (Table 19) $\mathrm{R}$ is a measure of the correlation between predicted and observed values of the outcome. $R$ square is the amount of variance accounted for by the model. This is an important statistic because its magnitude is an indication of the model's prediction power. In our Model Summary Table, we can see that about $13 \%$ of the variance in the model can be predicted by our two independent variables. Adjusted R square shows the variation that the model could show had it been driven from other samples of the same population. The standardrd error of the measurement too is the average deviation of the predicted values (Ys) from the mean of the predicted values $(\overline{\mathrm{Y}})$ squared.

Table 19: Model Summary

\begin{tabular}{|c|c|c|c|c|}
\hline Model & $\mathbf{R}$ & $\begin{array}{c}\mathbf{R} \\
\text { Square }\end{array}$ & $\begin{array}{c}\text { Adjusted } \\
\text { R Square }\end{array}$ & $\begin{array}{c}\text { Std. Error of the } \\
\text { Estimate }\end{array}$ \\
\hline 1 & $.358^{\mathrm{a}}$ & .128 & \multicolumn{2}{c|}{$\begin{array}{c}7.059 \\
\text { a. Predictors: (Constant), Collective efficacy belief, Interpersonal emotion regulation }\end{array}$} \\
\hline
\end{tabular}

The ANOVA table is important because it shows whether the model has been effective enough in predicting the outcome. The p-value for our ANOVA test is $.046<.05$, which means the model is significantly predicting preparatory teachers' job stress. However, the coefficients table needed to be examined (Table 21) to figure out what the source of this prediction power is.

Table 20: ANOVA Test of the Effects of Collective Efficacy Belief and Interpersonal Emotion Regulation on Preparatory Teachers' Job Stress

\begin{tabular}{|c|c|c|c|c|c|c|}
\hline \multicolumn{2}{|c|}{ Model } & Sum of Squares & df & Mean Square & $\mathbf{F}$ & Sig. \\
\hline \multirow[t]{3}{*}{1} & Regression & 328.864 & 2 & 164.432 & 3.303 & $.046^{\mathrm{b}}$ \\
\hline & Residual & 2240.115 & 45 & 49.780 & & \\
\hline & Total & 2568.979 & 47 & & & \\
\hline \multicolumn{7}{|c|}{ a. Dependent variable: Perceived job stress } \\
\hline \multicolumn{7}{|c|}{ b. Predictors: (Constant), Collective efficacy belief, Interpersonal emotion regulation } \\
\hline
\end{tabular}

The Coefficients Table (Table 21) was interesting in that while high levels of collective efficacy belief were not predictive of preparatory teachers' perceived job stress, the variable as a whole is predictive of this attribute. As can be seen, $p=.022<.05$ and the beta value is -.396. This Beta value means that, each unit of increase in collective efficacy belief will result in 396 unit decrease in perceived job stress. But interpersonal emotion regulation is almost unable to predict any change in stress. 
Table 21: Coefficients of Collective Efficacy Belief and Interpersonal Emotion Regulation

\begin{tabular}{|c|c|c|c|c|c|c|}
\hline \multirow{2}{*}{\multicolumn{2}{|c|}{ Model }} & \multicolumn{2}{|c|}{$\begin{array}{l}\text { Unstandardized } \\
\text { Coefficients }\end{array}$} & \multirow{3}{*}{$\begin{array}{c}\begin{array}{c}\text { Standardized } \\
\text { Coefficients }\end{array} \\
\text { Beta } \\
\end{array}$} & \multirow[t]{2}{*}{$\mathbf{t}$} & \multirow{2}{*}{ Sig. } \\
\hline & & B & Std. Error & & & \\
\hline \multirow{3}{*}{1} & (Constant) & 31.927 & 5.095 & & 6.266 & .000 \\
\hline & Interpersonal emotion regulation & .037 & .076 & .081 & .481 & .633 \\
\hline & Collective efficacy belief & -.410 & .173 & -.396 & -2.366 & .022 \\
\hline
\end{tabular}

a. Dependent variable: Perceived job stress

The conclusion that can be reached was that enhancing collective efficacy belief would reduce the tension that language teachers experience in the form of stress in university preparatory programs.

\section{Discussion}

Job stress is a complex psychological phenomenon. Stress perceived by EFL teachers can be influenced by numerous variables contributing to the amount of stress teachers experience in their careers. The findings of this study revealed that selected EFL teachers' perceived collective efficacy beliefs and job stress were negatively related. That means when teachers felt high collective efficacy beliefs their level of job stress diminish. In addition, teachers' perceived collective efficacy beliefs and their emotion regulation were positively related; the teachers with higher collective efficacy beliefs better regulate their own emotions. The relationship between teachers' level of job stress and their interpersonal emotional regulation, meanwhile, was found to be related but there was not any strong correlation. This means that these two variables were independent of each other, i.e. high level of teacher collective efficacy does not necessarily result in better regulation of emotions or vice versa. With respect to the demographic information, teachers' age and years of teaching experience were found not to be related to job stress.

The target population in our study was a sample of 48Turkish EFL instructors working at university English preparatory programs in Turkey Therefore, the results of the study can only be generalized to this group of instructors and findings should be interpreted accordingly. That is to say that the results of the present study offer insights to a clear understanding of the selected university preparatory school EFL teachers' problems, allowing us to reflect on what needs to be done to induce stress-free teaching environments. Given that in this study language teachers' collective efficacy beliefs are a strong contributor to predicting teachers' perceived job-related stress. This finding is consistent with the other studies in the literature in which teachers' beliefs about collective capabilities are positively related to job satisfaction (Goddard, Hoy, \& Hoy, 2000; Klassen, Usher, \& Bong, 2010; Sampson, Morenoff, \& Earls, 2000). 


\section{Conclusion}

The findings of our study suggest the necessity of improvement in two major areas in teachers' schools. That is to say that increasing the qualities of the work environment that are conducive to teacher collegiality and, providing training on how to regulate emotions in the workplace would likely increase language teachers' collective efficacy beliefs, which in turn will reduce their perceived job stress.

There are a few implications of this study for teachers' job stress not only for English language instructors but also for the teachers in general. First of all, it is apparent that a collegial and collaborative school environment is a key to emotionally healthy teachers. When there is a lack of professional support in an educational institution, there is a high risk of teachers dealing with stress and losing their confidence in their professional skills (Friedman, 2003).

The findings may be of interest to prep school administrative bodies educators whose responsibility is to ensure that teacher job satisfaction matters along with their emotional health, in a workplace where teachers are not supported by the school administration teachers may lose their commitment to teaching. Furthermore, stress among teachers may have short- and long-term effects on their both professional and personal lives, that is why necessary measures need to be taken to guide teachers in coping with negative feelings in the workplace.

The findings of the study might indicate that external factors such as organizational structure, teacher-student relationship and, the school environment may play a more important role than individual factors in terms of teacher stress. With this respect, it might be inferred that school administrations could have a crucial impact on regulating the working conditions and thus, affecting the level of job stress experienced by the teachers.

EFL teachers' job stress can be affected by various factors such as personal, psychological and contextual factors, future research can look into the contribution of other job-related stress factors, as in the effect of curriculum, students' level of English language proficiency, and poor working conditions in the understanding of the stress level teachers have in their language teaching profession.

For further studies, firstly it can be recommended that the researchers might include other affective factors such as teacher motivation, student motivation, or students' engagement. In addition, the relationship between the level of EFL teachers' perceived job stress and more detailed demographic features such as teachers' marital status, type of position they hold, and type of school they work in need to be included.

\section{Conflict of Interest Statement}

The authors declare no conflicts of interest. 


\begin{abstract}
About the Authors
Ilknur Eginli is an Assistant Professor in the Department of English Language Teaching at Istanbul Medipol University, Turkey. Her research interest centers on psychology of language learner and teacher; more specifically, the role of emotions in teaching and learning, teachers' professional development and self-beliefs.

Aynur Kesen Mutlu is an Associate Professor in the Department of English Language Teaching at Istanbul Medipol University, Turkey. Her research interests are intercultural communication, teacher effectiveness, and teacher professional development.
\end{abstract}

\title{
References
}

Baleghizadeh, S., \& Goldouz, E. (2016). The relationship between Iranian EFL teachers' collective efficacy beliefs, teaching experience and perception of teacher empowerment. Cogent Education, 3, 1-15. doi:10.1080/2331186X.2016.1223262

Borg, M. C. (1990). Occupational stress in British educational settings: A review. Educational Psychology, 10, 103-126

Borg, M. G., \& Riding, R. J. (1991). Occupational stress and satisfaction in teaching. British Educational Research Journal, 17, 263 - 281.

Bolton, A. (2018). Teachers' job satisfaction, stress, self-efficacy and beliefs about selfregulated learning. Undergraduate Honors Theses. 68. https://ir.lib.uwo.ca/psychK uht/68

Brackett, M. A., Palomera, R., Mojsa-Kaja, J., Reyes, M., \& Salovey P. (2010). EmotionRegulation Ability, Burnout, and Job Satisfaction among British Secondary-School Teachers. Psychology in the Schools, 47(4), 406-417

Bulut, N. (2005). The Relationship Between Life Events that Produce Stress in Primary School Teachers and Teachers' Styles in Handling Stress. Kastamonu Education Journal, Vol. 13(2), 467-478.

Ciani, K. D., Summers, J. J., \& Easter, M. A. A. (2008). Top-down analysis of high school teacher motivation. Contemporary Educational Psychology, 33, 533-560.

Cohen, S., Kamarck, T., \& Mermelstein, R. (1983). A global measure of psychological stress. Journal of Health and Social Behavior, 24, 385- 396.

Cohen, S., \& Williamson, G. (1988). Psychological stress in a probability sample of the United States. In S. Spacapan \& S. Oskamp (Eds.), The social psychology of health: Claremont Symposium on Applied Social Psychology (pp. 31-67). Newbury Park, CA: Sage.

Dawn S., Talukdar P., Bhattacharjee S., Singh O. P. (2017). A study on job related stress among school teachers in different schools of West Bengal, India. Eastern Journal of Psychiatry; 19(1):12-17.

Dornyei, Z. (2001). Teaching and Researching Motivation. England: Pearson Education Limited. 
Fathi J., Greenier V., Derakhshan A. (2021). Teacher self-efficacy, reflection, and burnout among Iranian EFL teachers: the mediating role of emotion regulation. Iranian Journal of Language Teaching Research. 9, 13-37.

Friedman, I. A. (2003). Self-efficacy and burnout in teaching: The importance of interpersonal relations efficacy. Social Psychology of Education,6, 191-215.

Friedman, I. A., \& Kass, E. (2002). Teacher self-efficacy: A classroom-organization conceptualization. Teaching and Teacher Education, 18, 675-686.

Good, T. L. and Brophy, J. E. (1994). Looking in classrooms. 6th edition. New York: Harper Collins.

Gross, J. J. (2001). Emotion regulation in adulthood: timing is everything. Curr. Dir. Psychol. Sci. 10, 214-219.

Gross, J. J. (2015). Emotion regulation: current status and future directions. Psychol. Inq. 26, 1-26.

Garnefski, N., \& Kraaij, V. (2006). Relationships between cognitive emotion regulation strategies and depressive symptoms: A comparative study of five specific samples

Gibson, S., \& Dembo, M. (1984). Teacher efficacy: A construct validation. Journal of Educational Psychology, 76, 569-582.

Greenier, V., Derakhshan, A., \& Fathi, J. (2021). Emotion regulation and psychological well-being in teacher work engagement: A case of British and Iranian English language teachers. System, 97, 102446.

Greenglass, E. R., \& Burke, R. J. (2003). Teacher stress. In M. F. Dollard, A. H. Winefield, \& H. R. Winefield (Eds.), Occupational stress in the service professions (pp. 213236). New York, NY: Taylor and Francis.

Goddard, R. D., \& Goddard, Y. L. (2001). A multilevel analysis of the relationship between teacher and collective efficacy in urban schools. Teaching and Teacher Education, 17, 807-818.

Goddard, R. D. (2002). Collective efficacy and empirical analysis of the measurement of collective efficacy: The development of a short form. Educational and Psychological Measurement, 61(6), 1071-1084.

Goddard, R., Goddard, Y., Kim, E. S., \& Miller, R. (2015). A theoretical and empirical analysis of the roles of instructional leadership, teacher collaboration, and collective efficacy beliefs in support of student learning. American Journal of Education, 121(4), 501-530. doi:10.1086/681925

Goddard, R. D., Hoy, W. K., \& Woolfolk Hoy, A. (2000). Collective teacher efficacy: Its meaning, measure, and impact on student achievement. American Educational Research Journal, 37, 479-508.

Goddard, R. D., \& LoGerfo, L. F. (2007). Measuring emergent organizational properties: A structural equation modeling test of self- versus group-referent perceptions. Educational and Psychological Measurement, 67, 845-858.

Hofmann, S. G., Carpenter, J. K., \& Curtiss, J. (2016). Interpersonal Emotion Regulation Questionnaire (IERQ): Scale Development and Psychometric Characteristics. 
Cognitive therapy and research, 40(3), 341-356. https://doi.org/10.1007/s10608016-9756-2

İpek, H., Akçay, A., Atay, S. B., Berber, G., Karalık, T., \& Yılmaz, T. S. (2018). The relationship between occupational stress and teacher self-efficacy: A study with EFL instructors. Anadolu Journal of Educational Sciences International, 8(1): 126-150

Jepson, E. \& Forrest, S. (2006). Individual Contributory Factors in Teacher Stress: The Role of Achievement Striving and Occupational Commitment. British Journal of Educational Psychology, 76(1), 183-197.

John, O. O. \& Gross J. J. (2004). Healthy and unhealthy emotion regulation: Personality processes, individual differences, and life span development Journal of Personality, 72 pp. 1301-1334

Klassen, R. M., Usher, E. L. \& Bong, M. (2010). Teacher's Collective Efficacy, Job Satisfaction, and Job Stress in Cross-Cultural Context. The Journal of Experimental Education, 78(4), 464-486.

Kyriacou, C. (2001). Teacher Stress: Directions for Future Research. Educational Review, 53(1), 27-35.

Kyriacou, C. (2000). Stress busting for teachers. Cheltenham, UK: Stanley Thornes.

O'Connor, P. R. and Clark, V. A. (1990). ‘Determinants of Teacher Stress', Australian Journal of Education 34: 41-51.

Lazarus, R. S. (1999). The Cognition-Emotion Debate: A Bit of History. In Dalgleish, T., \& Power M. J. (Eds.), Handbook of Cognition and Emotion (3-20). New York, NY: John Wiley.

Lazarus, R. S., \& Lazarus, B. N. (1994). Passion and Reason: Making Sense of Our Emotions. New York, NY: Oxford University Press.

McRae, K., Hughes, B., Chopra, S., Gabrieli, J. D. E., Gross, J. J., \& Ochsner, K. N. (2009). The Neural Bases of Distraction and Reappraisal. Journal of Cognitive Neuroscience, 22(2), 248-262.

Naring, G., Briet, M., \& Brouwers, A. (2006). Beyond demand-control: Emotional labour and symptoms of burnout in teachers. Work \& Stress, 20, 303-315.

Pehlivan-Aydın, İ. (2002). Stress at Work Life. 2. Edition. Ankara: Pegam A Publishing.

Ross, J. A., \& Gray, P. (2006). Transformational leadership and teacher commitment to organizational values: The mediating effects of collective teacher efficacy. School Effectiveness and School Improvement, 17, 179-199.

Rude, S., \& McCarthy, C. (2003). Brief report. Cognition and Emotion, 17, 799-806

Sass, D. A., Seal, A. K. \& Martin, N. K. (2011). Predicting teacher retention using stress and support variables. Journal of Educational Administration, 49 (2).

Smith, A., Brice, C., Collins, A., Mathews, V., \& McNamara, R. (2000). The scale of occupational stress. A further analysis of the impact of demographic factors and type of job, HSE Books, UK.

Stoeber, J., \& Rennert, D. (2008). Perfectionism in school teachers: relations with stress appraisals, coping styles, and burnout. Anxiety, Stress, \& Coping. An International Journal, 21, 37e53. 
Sutton, R., \& Wheatley, K. F. (2003). Teacher's Emotions and Teaching: A Review of the Literature and Directions for Future Research. Educational Psychology Review, 15(4), 327-358.

Sutton, R. (2005). Teacher's Emotions and Classroom Effectiveness: Implications from Recent Research. Clearing House: A Journal of Educational Strategies, 78(5), 229-234.

Sutton, R. E., Mudrey-Camino, R., Knight, C. C. (2009). Teachers' Emotion Regulation and Classroom Management. Theory Into Practice, 48(2), 130-137.

Voelkel, R. H., \& Chrispeels, J. H. (2017). Understanding the link between professional learning communities and teacher collective efficacy. School Effectiveness and School Improvement, 28(5), 1-22. doi:10.1080/ 09243453.2017.1299015

Weinstein, T. L. \& Trickett, E. J. (2016). The development of an instrument to measure English Language Learner (ELL) teacher work stress. Teaching and Teacher Education: An International Journal of Research and Studies, 55(1), 24-32. 
Creative Commons licensing terms

Authors will retain the copyright of their published articles agreeing that a Creative Commons Attribution 4.0 International License (CC BY 4.0) terms will be applied to their work. Under the terms of this license, no permission is required from the author(s) or publisher for members of the community to copy, distribute, transmit or adapt the article content, providing a proper, prominent and unambiguous attribution to the authors in a manner that makes clear that the materials are being reused under permission of a Creative Commons License. Views, opinions, and conclusions expressed in this research article are views, opinions and conclusions of the author(s). Open Access Publishing Group and European Journal of English Language Teaching shall not be responsible or answerable for any loss, damage or liability caused in relation to/arising out of conflict of interests, copyright violations and inappropriate or inaccurate use of any kind content related or integrated on the research work. All the published works are meeting the Open Access Publishing requirements and can be freely accessed, shared, modified, distributed and used in educational, commercial and non-commercial purposes under a Creative Commons Attribution 4.0 International License (CC BY 4.0). 